П. В. Ставніченко, А. М. Антоненко, О. П. Вавріневич, О. В. Стеценко, С. Т. Омельчук, В. Г. Бардов ІНСТИТУТ ГІГІЕНИ ТА ЕКОЛОГІЇ НАЦІОНАЛЬНОГО МЕДИЧНОГО УНІВЕРСИТЕТУ ІМЕНІ О. О. БОГОМОЛЬЦЯ, КИЇВ

\title{
ОПТИМІЗАЦІЯ АНАЛІТИЧНОГО КОНТРОЛЮ ЗАЛИШКОВИХ КІЛЬКОСТЕЙ ФУНГІЦИДІВ ЦИФЛУФЕНАМІДУ ТА ДИФЕНОКОНАЗОЛУ У ВОДІ
}

Вступ. Щорічно асортимент та обсяг застосування пестицидів поповнюються новими сполуками різних хімічних класів. Відомі способи визначення діючих речовин у воді методом газорідинної хроматографрії передбачають визначення тільки по одному фунгіциду, що є досить затратним. Тому залишається актуальною розробка способу, який дозволить одночасно визначити різні речовини в одній пробі. Така методика дасть можливість значно збільшити швидкість одного визначення та зменшити витрати на його проведення. Цей спосіб має не тільки економічне, а й екологічне значення, оскільки може ефективно використовуватись для моніторингових досліджень навколишнього середовища.

Мета дослідження - розробити методику аналітичного визначення мікрокількостей цифрлуфенаміду і дисреноконазолу при їх сумісній присутності у воді.

Методи дослідження. Дослідження включає екстрагування, концентрування та хроматографрування підготовлених проб води. Кількісне визначення цифрлуфенаміду та дифеноконазолу здійснювали методом газорідинної хроматографрії з використанням електронозахватного детектора.

Результати й обговорення. Найкращого результату з вилучення діючих речовин із проб води було досягнуто при використанні хлороформу як екстрагенту. Встановлено умови хроматографування, за яких час утримування становив: цифрлуфенаміду - 3,19 хв, дифреноконазолу - 12,58 хв. Межі кількісного визначення даного методу склали: для цифрлуфенаміду - 0,001 мг/дм³, дифееноконазолу - 0,001 мг/дм³.

Висновок. Розроблено умови одночасного визначення цифрлуфенаміду і дифеноконазолу методом газорідинної хроматографії при сумісній присутності в пробі води, що дозволяє значно прискорити аналіз та зменшити витрати на його проведення.

КЛЮЧОВІ СЛОВА: дифеноконазол; цифлуфенамід; фунгіциди; газорідинна хроматографія; вода.

ВСТУП. При аналізі застосування в Україні й у світі хімічного методу захисту рослин було зроблено висновок, що асортимент пестицидів, препаративні форми і способи їх використання докорінно змінилися порівняно з тими, що були поширені в другій половині минулого сторіччя [1]. Сучасні препарати краще збалансовані за багатьма показниками, часто в їх складі міститься 2-3 діючих речовини, що розширює спрямованість і спрощує дозування та приготування робочих розчинів для їх застосування [1].

Серед фрунгіцидів для застосування на плодових та овочевих культурах рекомендують препарати "Циделі Топ" і “Диналі" на основі діючих речовин дисеноконазолу (125 г/л) та цифрлуфенаміду (15 г/л) [2]. Зазначені препарати задо-

() П. В. Ставніченко, А. М. Антоненко, О. П. Вавріневич, О. В. Стеценко, С. Т. Омельчук, В. Г. Бардов, 2017. вольняють сучасні вимоги, а їх діючі речовини рекомендовані у світі для захисту багатьох плодових та овочевих культур. 3 огляду на велику кількість комбінованих препаратів на основі диореноконазолу [2] й антирезистентну стратегію застосування пестицидів, яка передбачає використання сполук з новим механізмом дії та впровадження комбінованих препаратів на основі двох і більше діючих речовин, можливе активне застосування дифеноконазолу з іншими діючими речовинами в одному регіоні, а тому існує ймовірність їх одночасного надходження в об'єкти довкілля.

Для контролю за дотриманням гігієнічних норм цифрлуфенаміду та дифеноконазолу у воді раніше було розроблено аналітичні способи визначення кожної речовини окремо методом газорідинної хроматографрії [3, 4]. Відомі способи 
визначення діючих речовин у воді цим методом передбачають визначення тільки по одному фрунгіциду, що є досить затратним як з позиції часу, так і з позиції коштів. Саме тому актуальною залишається розробка способу, який дозволить одночасно визначити обидві діючі речовини препаратів “Циделі Топ" та “Диналі” в одній пробі. Така методика дасть можливість значно збільшити швидкість одного визначення та зменшити витрати на його проведення.

Мета дослідження - розробити методику аналітичного визначення мікрокількостей цифрлуоренаміду і диореноконазолу при їх сумісній присутності у воді.

МЕТОДИ ДОСЛІДЖЕННЯ. Діючі речовини, які досліджували, за своїми хімічними властивостями належать до різних хімічних класів: похідних амід фенілоцтової кислоти (цисллуфенамід) і заміщених триазолів (дифеноконазол).

Структурні фрормули та фрізико-хімічні властивості досліджуваних сполук наведено в таблиці $[5,6]$.

При розробці аналітичного методу визначення досліджуваних сполук вносили аналітичні стандарти цифрлуфенаміду та дифреноконазолу 3 вмістом діючої речовини 2,0 мкг/мл у 2000 л води.

Вихідний стандартний розчин кожної з досліджуваних речовин містив 100 мкг/мл сполуки в 1 мл гексану. Шляхом змішування та послідовного розведення цих вихідних розчинів ацетонітрилом готували 5 робочих градуювальних роз- чинів суміші досліджуваних речовин з масовою концентрацією кожної сполуки 1,0; 2,0; 5,0; 8,0 і 10,0 мкг/мл та контрольний розчин суміші з масовою концентрацією кожної сполуки 4,0 мкг/мл.

Дослідження виконано методом газорідинної хроматограсрії на хроматограсрі "Кристаллюкс-400 М", оснащеному капілярною колонкою НР-5, з електронозахватним детектором. Спочатку проводили хроматографрічний аналіз розчину кожної речовини для подальшої ідентифікації піку конкретної сполуки на хроматограмі суміші. Після вибору оптимальних умов розділення цифрлуфенаміду і дифеноконазолу хроматограсування кожного градуювального розчину суміші проводили 5 разів для побудови графріків залежності висоти хроматографічного піку кожної сполуки від концентрації.

Ідентифрікацію досліджуваних сполук в екстрактах проб води проводили за часом утримування кожної з двох речовин у градуювальних розчинах суміші, кількісне визначення - за відповідною залежністю площі хроматографічного піку речовини від концентрації в градуювальному розчині, яку встановлювали на підставі кореляційного та регресійного аналізу [7].

РЕЗУЛЬТАТИЙ ОБГОВОРЕННЯ. ПРОбУ ВОДИ (2000 мл) було розділено на 4 проби по 500 мл. Проби води поміщали в ділильну лійку місткістю 1000 мл, додавали 5 г $\mathrm{NaCl}$ та проводили екстракцію цисрлуфенаміду і дифеноконазолу тричі різними екстрагентами (хлороформ, ксилол, метанол). Найкращого результату з вилу-

Таблиця - Основні фрізико-хімічні властивості цифлуфенаміду та дифеноконазолу

\begin{tabular}{|c|c|c|}
\hline \multirow{2}{*}{ Назва показника } & \multicolumn{2}{|c|}{ Значення показника для досліджуваних речовин } \\
\hline & цифрлуфенам & дифеноконазол \\
\hline Структурна фрормула & & \\
\hline Емпірична фрормула & $\mathrm{C}_{20} \mathrm{H}_{17} \mathrm{~F}_{5} \mathrm{~N}_{2} \mathrm{O}_{2}$ & $\mathrm{C}_{19} \mathrm{H}_{17} \mathrm{CL}_{2} \mathrm{~N}_{3} \mathrm{O}_{3}$ \\
\hline Реєстраційний номер CAS & $180409-60-3$ & $119446-68-3$ \\
\hline Молекулярна маса, г/моль & 412,36 & 406,3 \\
\hline Температура плавлення, ${ }^{\circ} \mathrm{C}$ & $61,5-62,5$ & $72-75$ \\
\hline Тиск пари $\left(20^{\circ} \mathrm{C}\right)$, Па & $3,54 \times 10^{-5}$ & $3,3 \times 10^{-8}\left(25^{\circ} \mathrm{C}\right)$ \\
\hline Розчинність у воді $\left(20^{\circ} \mathrm{C}\right)$, мг/дм ${ }^{3}$ & 0,52 & 20 \\
\hline $\begin{array}{l}\text { Розчинність в органічних } \\
\text { розчинниках }\left(25^{\circ} \mathrm{C}\right), \text { г/дм }{ }^{3}\end{array}$ & $\begin{array}{c}\text { н-гептан - 15,7, } \\
\text { н-гексан - 18,6, } \\
\text { метанол - 198, } \\
\text { ксилол - } 217\end{array}$ & $\begin{array}{l}\text { етанол - 330, } \\
\text { ацетон - 610, } \\
\text { толуол - 500, } \\
\text { н-гексан - 3,4 }\end{array}$ \\
\hline $\begin{array}{l}\text { Коефріцієнт розподілу } \\
\text { н-октанол/вода }\left(20^{\circ} \mathrm{C}\right)\end{array}$ & $\log P_{o / 8}=4,7$ & $\log \mathrm{P}=4,2$ \\
\hline
\end{tabular}


чення досліджуваних діючих речовин із проб води було досягнуто при використанні хлороформу як екстрагенту (тричі по 30 мл). Лійку струшували впродовж 1-2 хв, і після розділення шарів збирали хлосрормний шар у конічну колбу місткістю 250 мл. Об'єднаний екстракт сушили безводним сульфратом натрію (20-25 г) шляхом настоювання в конічній колбі місткістю 250 мл протягом 30 хв.

У подальшому екстракт переносили в грушоподібну колбу для відгону розчинників місткістю 250 мл і концентрували на ротаційному випарнику при температурі водяної бані, не вищій $45^{\circ} \mathrm{C}$, до об'єму 0,2-0,3 мл. До сухого залишку випаровували розчинник на повітрі. Сухий залишок розчиняли в 1 мл гексану та переносили в градуювальну пробірку місткістю 10 мл.

Наступним етапом наших досліджень було встановлення оптимальних умов хроматограсрування для визначення вмісту цифлусренаміду і дисреноконазолу методом газової хроматографії.

Встановлено оптимальні умови розділення та визначення цифрлусренаміду і дифееноконазолу: хроматограсрічна капілярна колонка HP-5 (довжина - 30 м, внутрішній діаметр - 0,32 мм); температура термостата колонки - $(260 \pm 2){ }^{\circ} \mathrm{C}$; температура випарника $-(280 \pm 2)^{\circ} \mathrm{C}$; температу- ра підігріву детектора - $(300 \pm 2){ }^{\circ} \mathrm{C}$; об'ємна витрата газу-носія (азоту) (газ-1) - $(30 \pm 0,1) \mathrm{M} / \mathrm{XB}$; об'ємна витрата газу-носія (азоту) (газ-2) $(10 \pm 0,1)$ мл/хв; об'ємна витрата газу-носія (азоту) (газ-3) - $(20 \pm 0,1)$ мл/хв; тиск - 0,8 атм. Режим "Спліт": об'ємна витрата газу-носія (азоту) (газ-1) - $(30 \pm 0,1)$ мл/хв, газу-носія (азоту) (газ-2) - $(10 \pm 0,1)$ мл/хв; затримка включення -5 с. Ідентифрікацію піків діючих речовин здійснювали за зовнішнім стандартом. В установлених умовах хроматографування час утримування становив: цифллусенаміду - 3,19 хв, дисреноконазолу - 12,58 хв.

Хроматограми екстрактів проб води 3 внесенням по 0,001 мг/дм³ цисрлуфренаміду і дифе-ноконазолу наведено на рисунку.

Для обчислення масової концентрації ( $\rho$, $\mathrm{Mг} / \mathrm{CM}^{3}$ ) використовували фоормулу:

$$
X=\frac{C \times H_{2} \times V_{2} \times V_{3} \times 100}{H_{1} \times V_{1} \times P \times R},
$$

де $X$ - вміст цифрлуфренаміду (дифеноконазолу), мг/дм

C - концентрація стандартного розчину цифрлуфренаміду (дифеноконазолу), мкг/мл;

$\mathrm{H}_{1}$ - висота хроматографрічного піку стандарту цифрлуфенаміду (дифеноконазолу), мм;
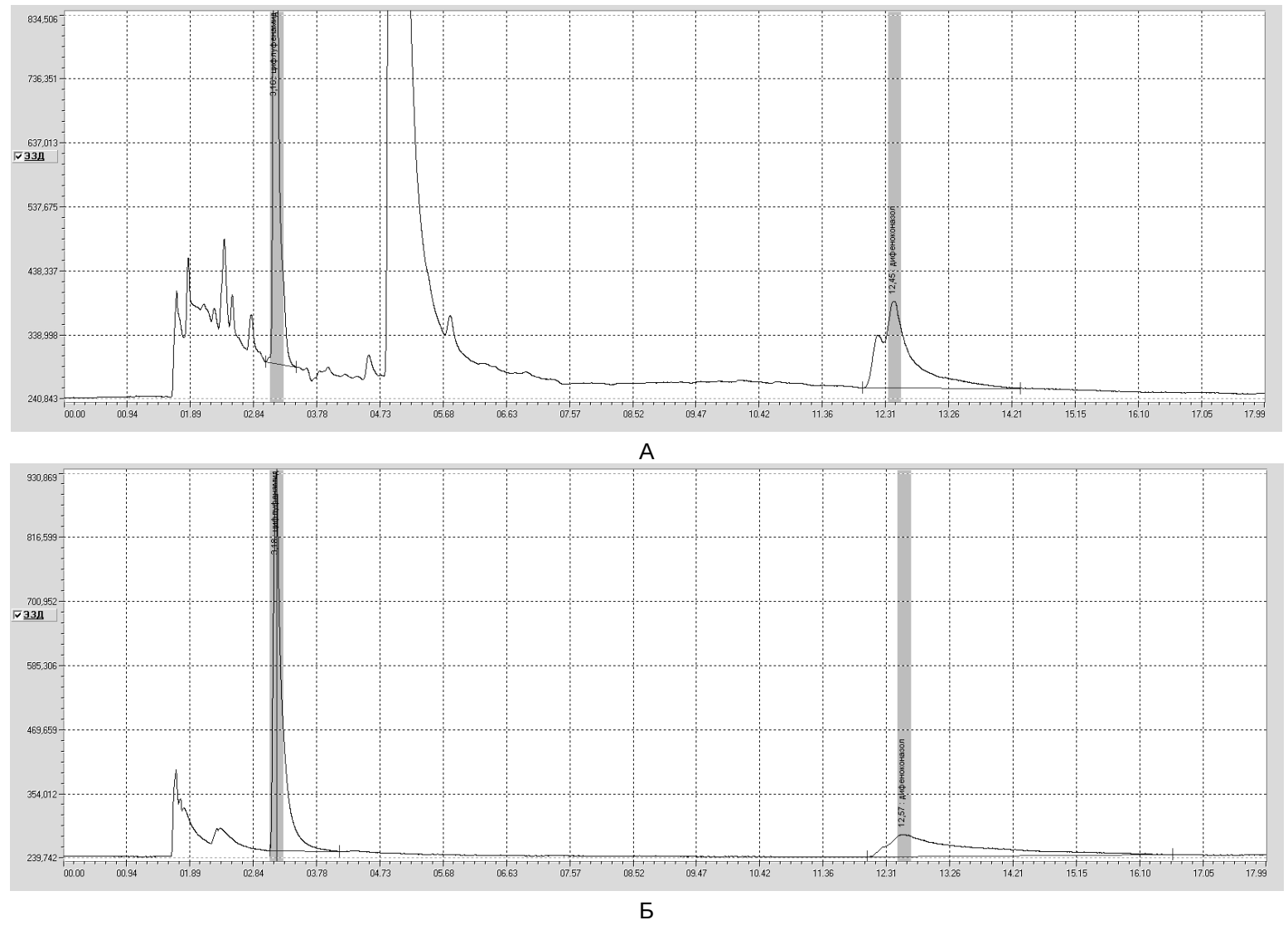

Рис. Хроматограми екстрактів проб води з внесенням по 0,001 мг/дм³ цифллуренаміду та дисреноконазолу: А - проба води з вмістом цифрлусенаміду та дифеноконазолу 5+10 мкг/мл; Б - суміш стандартного розчину цифрлуфенаміду та дифеноконазолу 5+10 мкг/мл. 
$\mathrm{H}_{2}$ - висота хроматографрічного піку цифрлуфренаміду (дифеноконазолу) в пробі, мм;

$V_{1}$ - аліквота кінцевого розчину проби, введена в хроматограср, мкл;

$V_{2}$ - загальний об'єм упареного екстракту проби, мл;

$V_{3}$ - об'єм стандартного розчину цисрлусенаміду (дифеноконазолу), введений у хроматографр, мл;

$P$ - об'єм проби, мл;

$R$-середнє значення визначення, знайдене напередодні, \%.

Визначення R проводили попередньо шляхом внесення відомих кількостей цифрлусренаміду та дисеноконазолу в контрольні зразки води відповідно до даної методики.

\section{СПИСОК ЛІТЕРАТУРИ}

1. Трибель С. О. Сучасний стан хімічного методу захисту рослин / С. О. Трибель, О. О. Стригун, О. М. Гаманова // Карантин і захист рослин. - 2014. - № 1 (210). - C. 1-4.

2. Перелік пестицидів і агрохімікатів, дозволених до використання в Україні (Офіційне видання) / [упоряд. В. У. Ящук, В. М. Ващенко, Р. М. Кривошия та ін.] К. : Юнівест Медіа, 2016. - 1086 с.

3. Тимчасові методичні вказівки з визначення цифрлуфренаміду у воді методом газорідинної хроматограсріï. № 1294-2014.

4. Методические указания по газохроматографическому определению дисееноконазола (СКОРА) в растительном материале, почве, воде. № 6147-91 // Методические указания по определению микроколичеств пестицидов в пищевых продуктах, кормах и
ВИСНОВКИ. 1. Розроблено умови одночасного визначення цифрлуфенаміду і дифреноконазолу методом високоефрективної рідинної хроматограсрії при сумісній присутності в пробі води, що дозволяє значно прискорити аналіз та зменшити витрати на його проведення.

2. Межі кількісного визначення розробленого методу для цифллуренаміду та дифреноконазолу 0,001 мг/дм ${ }^{3}$ дозволяють контролювати встановлені для цих речовин гігієнічні нормативи у воді.

3. Упровадження розробленого методу в практику роботи Міністерства екології та природних ресурсів України сприятиме вдосконаленню моніторингу пестицидів у довкіллі та проведенню заходів з мінімізації їх шкідливої дії на здоров'я населення.

внешней среде : [сб. 22, часть 1]. - К. : УКРГОСХИМкОМИССИЯ, 1995. - С. 59-64.

5. PPDB: Pesticide Properties Data Base [Електронний ресурс]: Cyflufenamid - Електронні дані. - Режим доступу: http://rupest.ru/ppdb/cyflufenamid.html. - Назва з екрану.

6. PPDB: Pesticide Properties Data Base [Електронний ресурс]: Difenoconazole. - Електронні дані. Режим доступу: http://rupest.ru/ppdb/difenoconazole. html. - Назва з екрану.

7. Международный стандарт ISO 0 8466-1:1990 (E). Качество воды - Калибровка и оценка аналитических методов определения рабочих характеристик. Часть 1 : Статистическая обработка линейной калибровочной функции. $-10 \mathrm{c}$.

\section{REFERENCES}

1. Trybel, S.O. Stryhun, O.O., \& Hamanova, O.M. (2014). Suchasnyi stan khimichnoho metodu zakhystu roslyn [The current state of the chemical method of plant protection]. Karantyn i zakhyst roslyn - Quarantine and Plant Protection, 1 (210), 1-4 [in Ukrainian].

2. Yashchuk, V.U., Vashchenko, V.M., \& Kryvoshyia R.M. (2014). Perelik pestytsydiv i ahrokhimikativ, dozvolenykh do vykorystannia v Ukraini (Ofitsiine vydannia) [The list of pesticides and agrochemicals permitted for use in Ukraine (official publication)]. Kyiv: Yunivest Media [in Ukrainian].

3. Tymchasovi metodychni vkazivky z vyznachennia tsyflufenamidu $u$ vodi metodom hazoridynnoi khroma- tohrafii [Temporary guidance on the determination of dimethylfenamide in water by gas-liquid chromatography]. No. 1294-2014 [in Ukrainian].

4. (1995). Metodicheskie ukazaniya po hazokhromatograficheskomu opredeleniyu dyfenokonazola (SKORA) v rastitelnom materiale, pochve, vode [Guidances on gas chromatographic determination of diphenoconazole (SCAR) in vegetative material, soil, water]. (1995). Metodicheskie ukazaniya po opredeleniyu mikrokolichestv pestitsydov $v$ pishchevykh produktakh, kormakh $i$ vneshney srede - Methodical guidelines for the determination of pesticide microcosms in food products, feeds and the environment]. Kyiv: UKRGOSKHIMKOMISSIYA [in Russian]. 
5. Pesticide Properties Data Base. Cyflufenamid. Retrieved from: http://rupest.ru/ppdb/cyflufenamid.html. (Assessed 12 of August 2017).

6. Pesticide Properties Data Base. Difenoconazole. Retrieved from: http://rupest.ru/ppdb/difenoconazole. html. (Assessed 12 of August 2017).
7. International standart ISO 0 8466-1:1990 (E). Kachestvo vody - Kalibrovka I otsenka analiticheskikh metodov opredeleniya rabochikh kharakteristik. Chast 1: Statisticheskaya obrabotka lineynoy kalibrovochnoy funktsii [Water quality - Calibration and evaluation of analytical methods for determining performance. Part 1: Statistical processing of linear gauge function]. [in Russian].

П. В. Ставниченко, А. Н. Антоненко, Е. П. Вавриневич, А. В. Стеценко, С. Т. Омельчук, В. Г. Бардов ИНСТИТУТ ГИГИЕНЫ И ЭКОЛОГИИ НАЦИОНАЛЬНОГО МЕДИЦИНСКОГО УНИВЕРСИТЕТА ИМЕНИ А. А. БОГОМОЛЬЦА, КИЕВ

\section{ОПТИМИЗАЦИЯ АНАЛИТИЧЕСКОГО КОНТРОЛЯ ОСТАТОЧНЫХ КОЛИЧЕСТВ ФУНГИЦИДОВ ЦИФЛУФЕНАМИДА И ДИФЕНОКОНАЗОЛА В ВОДЕ}

\section{Резюме}

Вступление. Ежегодно ассортимент и объем применения пестицидов пополняются новыми соединениями различных химических классов. Известные способы определения действующих веществ в воде методом газожидкостной хроматографии предусматривают определение только по одному фунгициду, что является достаточно затратным. Поэтому остается актуальной разработка способа, который позволит одновременно определить различные вещества в одной пробе. Такая методика даст возможность значительно увеличить скорость одного определения и уменьшить расходы на его проведение. Этот способ имеет не только экономическое, но и экологическое значение, поскольку может эффрективно использоваться для мониторинговых исследований окружающей среды.

Цель исследования - разработать методику аналитического определения микроколичеств цифлуфренамида и дифеноконазола при их совместном присутствии в воде.

Методы исследования. Исследование включает экстрагирование, концентрирование и хроматографрирование подготовленных проб воды. Количественное определение цифрлуфренамида и дифреноконазола осуществляли методом газожидкостной хроматографии с использованием электронозахватного детектора.

Результаты и обсуждение. Наилучшего результата по извлечению действующих веществ из проб воды было достигнуто при использовании хлороформа в качестве экстрагента. Установлены условия хроматографирования, при которых время удерживания составляло: цифрлуфенамида - 3,19 мин, дифреноконазола - 12,58 мин. Пределы количественного определения данного метода составили: для цифлу-

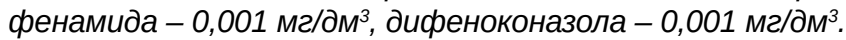

Вывод. Разработаны условия одновременного определения цифлуфренамида и дифеноконазола методом газожидкостной хроматографии при совместном присутствии в пробе воды, что позволяет значительно ускорить анализ и уменьшить расходы на его проведение.

КЛЮЧЕВЫЕ СЛОВА: дифреноконазол; цифрлуфенамид; фрунгициды; газожидкостная хроматография; вода. 
P. V. Stavnichenko, A. M. Antonenko, O. P. Vavrinevych,

O. V. Stetsenko, S. T. Omelchuk, V. G. Bardov

HIGIENE AND ECOLOGY INSTITUTE OF O. BOHOMOLETS NATIONAL MEDICAL UNIVERSITY, KYIV

\title{
METHOD OF SIMULTANEOUS DETERMINATION OF CYCLUFENAMIDE AND DIFENOCONAZOLE IN WATER
}

\begin{abstract}
Summary
Introduction. Annually, the assortment and application rates of pesticides are supplemented with new compounds of various chemical classes. Methods for the determination of active substances in water by the method of gas-liquid chromatography are known to provide for the determination of only one fungicide, which is quite costly. Therefore, it remains an actual goal to develop a method that will simultaneously identify different substances in one sample. Such a technique allows significantly increasing the speed of one definition and reducing the cost of conducting it. Such a method has not only economic but also ecological significance, since it can be effectively used for monitoring environmental studies.

The aim of the study - to develop a technique for the analytical determination of cyflufenamide and difenoconazole microquantities in water simultaneously.

Research Methods. Research includes extraction, concentration and chromatography of prepared water samples. The quantitative determination of cyflufenamide and difenoconazole was carried out by gas-liquid chromatography using an electron-capture detector.

Results and Discussion. The best result of active substances extraction from water samples was achieved using chloroform as an extractant. Chromatography conditions were established under which the retention time is: for cyflufenamide - 3.19 minutes; difenoconazole - 12.58 minutes. Limit of the quantification of this method for cyflufenamide is $0.001 \mathrm{mg} / \mathrm{dm}^{3}$, difenoconazole $-0.001 \mathrm{mg} / \mathrm{dm}^{3}$.

Conclusion. The conditions for simultaneous determination of cyflufenamide and difenoconazole by the method of gas-liquid chromatography are developed with their simultaneous presence in the water sample, which allows significantly speeding up the analysis and reducing the cost of conducting it.
\end{abstract}

KEY WORDS: difenoconazole; cyflufenamide; fungicides; gas-liquid chromatography; water.

Отримано 21.09.17

Адреса для листування: А. М. Антоненко, Інститут гігієни та екології Національного медичного університету імені О. О. Богомольчя, просп. Перемоги, 34, Київ, 03057, Україна, е-mail: antonenko198@ukr.net. 